RESEARCH ARTICLE

\title{
Training Need of MGNREGA Beneficiaries in Dharmapuri District of Tamil Nadu
}

\author{
V. Thirumal Kannan ${ }^{1}$ and T. Raj Pravin ${ }^{2 *}$ \\ ${ }^{1}$ Department of Agricultural Extension, Faculty of Agriculture, Annamalai University, Annamalai Nagar - 608 002, Tamil Nadu, India \\ $2 *$ Department of Agricultural Extension, Faculty of Agriculture, Annamalai University, Annamalai Nagar - 608 002, Tamil Nadu, India.
}

\begin{abstract}
The Mahatma Gandhi National Rural Employment Guarantee Act (MGNREGA) guarantees 100 days of employment in a financial year to any rural household whose adult members are willing to do unskilled manual work. A study was undertaken to assess the training needs of MGNREGA beneficiaries in the Dharmapuri district, one of the most backward districts of Tamil Nadu. A Proportionate random sampling method was used to select 120 respondents for this study. The data was collected using a well-structured and pre-tested interview schedule, and appropriate statistical tools were used for analysis. The findings of the study reveal that majority of the respondents expressed training needs on seven major subject areas i.e., Checking multiple entries in job cards, active participation in gram sabha meetings, operations of savings accounts in banks/ post office, Active participation in social audit, work allocation procedure and awareness on grievance redressal mechanisms. The majority preferred to have peripatetic training in their panchayat union office for a day during the summer season on forenoon session.
\end{abstract}

Keywords: MGNREGA, Training need areas; Training methods

\section{INTRODUCTION}

The Mahatma Gandhi National Rural Employment Guarantee Act (MGNREGA) is the largest social security scheme in the world implemented in our nation. This scheme provides a legal guarantee for one hundred days of employment in every financial year to all adult members of any rural household willing to do public-related unskilled manual work at the statutory minimum wage. The objective of the scheme is to enhance food and livelihood security to rural people by providing assured wage employment for a minimum of 100 days in a financial year. The creation of durable assets from these manual works would help in soil and water conservation towards natural resource conservation.

This long-term benefits of environmental enhancement is expected to increase farm production and productivity. Social security measures including poverty alleviation, employment generation are also important components of this scheme. MGNREGA started in three phases, the first phase in 2006 covering 200 districts, the second phase in 2007 2008 covering another 130 districts, and in the third and final phase, the remaining districts have been notified under NREGA with effect from $1^{\text {st }}$ April 2008. Our entire nation was brought under the purview of MGNREGA, with priority given to women's pay parity and gender equality. Being implemented in the lean season of the year, study on training needs is more important for the successful implementation of this programme for reaching its intended objectives. So keeping this in view, a study was undertaken to assess the training needs of MGNREGA beneficiaries in the Dharmapuri district of Tamil Nadu.

\section{RESEARCH METHODOLOGY}

Dharmapuri district in Tamil Nadu is one of the most backwards districts as identified by the State Planning Commission. It has eight blocks viz., Dharmapuri, Karimangalam, Nallampalli, Pappireddipatty, Harur, Morappur, Palakkodu and Pennagaram. Among these blocks Pennagaram block was purposively selected for this study as there was more number of beneficiaries registered under this social welfare scheme. A proportionate random sampling method was used to select 120 respondents. The data was collected using a well-structured interview schedule. Necessary efforts were made to cross-check the data collected from respondents in this study. The findings of this study are given below.

\section{FINDINGS AND DISCUSSION}

\section{Major Training need areas for MGNREGA beneficiaries}

Training is essential to gain new knowledge $107 \mid 10-12$ | 1 
and acquire new skill sets. The training need of the respondents in the study area, needed training methods and strategies are discussed below.
From the table- 1 , the following inferences can be drawn. Most needed training need areas, as identified by the respondents of this study are

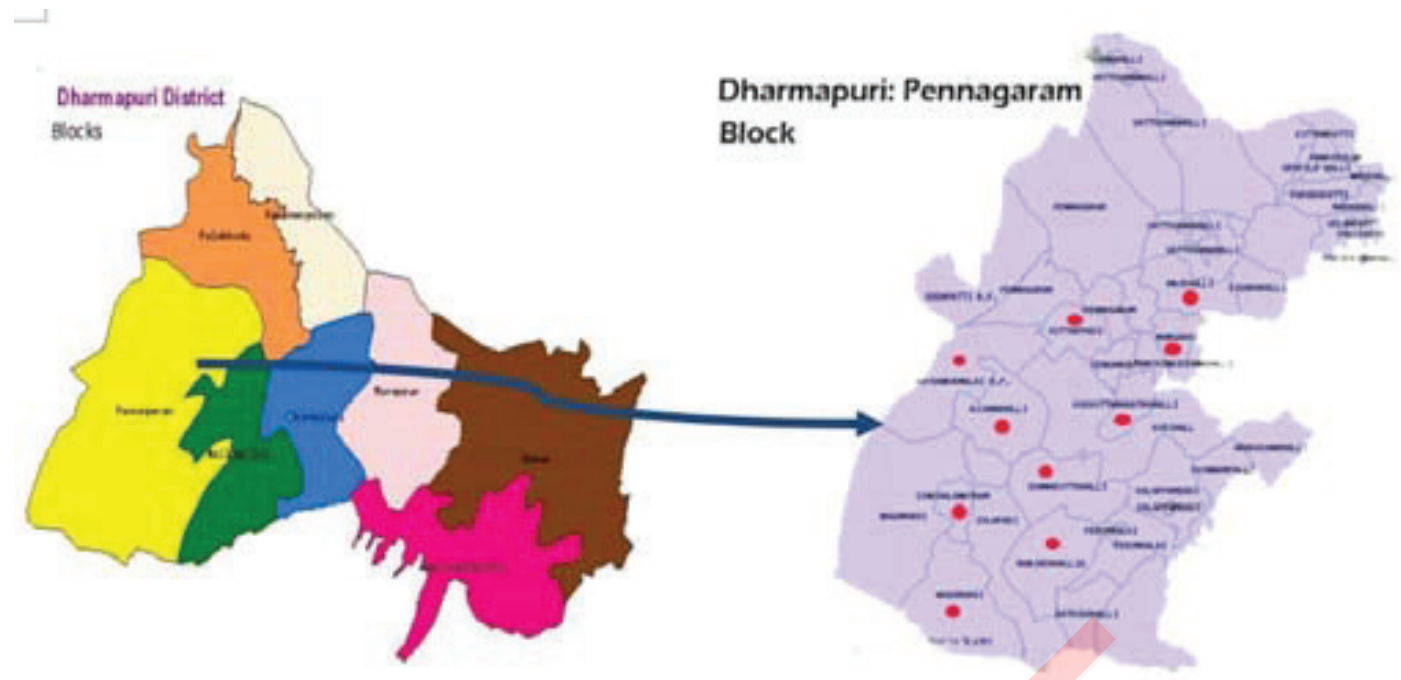

Selected Panchayat villages

Figure 1. Map showing the study area

\section{Checking multiple entries in job cards}

The respondents in this study area are mostly illiterate women from socially backward and disadvantaged communities. They are in need of training to check multiple entries made in job cards

Table 1. Training need areas $(n=120)$

\begin{tabular}{|c|c|c|c|c|c|c|}
\hline \multirow[t]{2}{*}{ Major subject areas } & \multicolumn{6}{|c|}{ Training need areas } \\
\hline & $\begin{array}{c}\text { Most } \\
\text { Needed }\end{array}$ & Per cent & Needed & Per cent & $\begin{array}{c}\text { Not } \\
\text { Needed }\end{array}$ & Per cent \\
\hline Checking multiple entries in job card & 109 & 90.84 & 11 & 9.16 & - & - \\
\hline $\begin{array}{l}\text { Active participation in Grama sabha } \\
\text { meetings }\end{array}$ & 109 & 90.84 & - & - & 11 & 9.16 \\
\hline $\begin{array}{l}\text { Operation of savings accounts in bank } \\
\text { / post office }\end{array}$ & 102 & 85.00 & 7 & 5.84 & 11 & 9.16 \\
\hline Active participation in social audit & 102 & 85.00 & 11 & 9.16 & 7 & 5.84 \\
\hline Work allocation procedure & 95 & 79.16 & 10 & 8.33 & 15 & 12.50 \\
\hline Grievances Redressal mechanisms & 95 & 79.16 & 22 & 18.34 & 3 & 2.50 \\
\hline Getting job card & 80 & 66.66 & 7 & 5.84 & 33 & 27.5 \\
\hline $\begin{array}{l}\text { Opening up of bank account / post } \\
\text { office savings }\end{array}$ & 60 & 50.00 & 49 & 40.84 & 11 & 9.16 \\
\hline $\begin{array}{l}\text { Differently abled/ Pregnant ladies/ } \\
\text { Transgender rights under MGNREGA } \\
\text { act }\end{array}$ & - & - & 11 & 9.16 & 109 & 90.84 \\
\hline
\end{tabular}

as many have this scheme as their major source of income and are dependent on it for meeting their daily and livelihood expenses. So 90.84 per cent of the respondents in this study has identified it as the most needed training followed by 9.16 per cent of respondents expressing needed training in this area.

\section{Active participation in Grama Sabha meetings}

In Tamil Nadu, Gram Sabha meetings are conducted four times in a year i.e. $26^{\text {th }}$ January, $1^{\text {st }}$ May, $15^{\text {th }}$ August and $2^{\text {nd }}$ October. During this gram sabha meeting, reports of earlier works undertaken, new welfare schemes to be implemented in the village, beneficiaries selection for welfare schemes needs to be discussed. The work is done under MGNREGA, the allotment and budgetary support, future work needs to be discussed and documented. However, in many villages, grama sabhas are conducting with just the quorum members. Being illiterate from socially backward communities, a majority (90.84 per cent) needed training to

$107 \mid 10-12$ | 2 
participate in grama sabha meetings and take part in all its deliberations and discussions. So this has been identified as one of the most important training need areas by the respondents of this study.

\section{Operations of Accounts in banks/ post offices}

The wages in the MGNREGA are paid through direct transfer from bank or post office savings account of individual beneficiaries. With many belonging to the old age category in this study from socially backward communities with poor educational status, they needed training in operating their savings accounts in nearby banks and post offices. Moreover, with funds disbursal being late, the workers need to visit banks/ post offices frequently to see their entries in their accounts and withdraw money for their daily and livelihood needs. This has made majority (50.00 per cent) of the respondents in the study area identify it as a most important training need, followed by 40.84 per cent expressing it as a needed area for training.

\section{Active participation in Social Audit}

The social audit has an important role in improving the effectiveness of this scheme and in reducing corruption associated with it. Institutionalization of social audit introduced at the behest of social movements needed the participation of all stakeholders associated with this scheme. So a majority (85.00 per cent) of participants of MGNREGS scheme has felt it as an important training needed, followed by 9.16 per cent expressing it as a needed training need. These findings derive support from Amarjeet Sinha (2019).

\section{Work allocation procedure}

The majority (79.16 per cent) of the participants of this scheme mostly needed training on the work allocation procedure followed in the scheme. As disbursal of funds are reduced by central and state governments work MGNREGA scheme work allocation is also getting drastically decreased. Due to political interference, the decreased work is also shared by supporters of people representatives or those close to bureaucracy. This has made majority of the respondents of this scheme express this as their most needed training. A small part of the respondents (13.50 per cent) are aware of the work allocation procedure followed under this welfare scheme.

\section{Grievances redressal mechanisms}

The MGNREGA has incorporated Grievance redressal mechanisms in its fold in the best interest of all stakeholders of this scheme. However, the majority of the participants of this scheme are not aware of it. This has made majority (79.16 per cent) of them identify it as the most needed training need area and 18.34 per cent expressing it as a needed training need.

\section{Getting job cards}

Earlier, getting job cards of MGNREGA was easier. During the early implementation of the scheme, applications were received and job cards were issued. However, over the years, when the allocation of funds was drastically reduced, the issue of new job cards was also reduced. In few villages in this study, no job cards were issued for a very long period as the names have to be entered in the e-muster rolls for getting job cards and shortage of employment assistants (Gram Rozgar Sevaks) in panchayats made getting job cards becoming a difficult task at the grass-root level. So there was a great need for getting job cards in villages during distress times. This has been identified as a most important training need by a majority (66.66 per cent) of the respondents in this study. One-third of the respondents do not need training as they have job cards and are not in need of any new job cards for their family members.

\section{Opening up of saving account in Bank/ Post offices}

Many of the respondents in the scheme received wages in their hands in the earlier stages of implementation of this scheme. However, to prevent corruption, wages were paid through Direct Transfer Mechanisms (DTMs) in the accounts of beneficiaries in nearby post offices or banks. Many have started savings account in bank or post offices to receive their wage payments. However, there is a still a huge need for opening savings account in banks and post office for receiving their wages. This has made them regard it as a most needed training need by 50.00 per cent and needed training by 40.84 per cent of the respondents in the study area.

\section{Training Needs Not Felt by Respondents}

\section{Differently abled/ Pregnant ladies/Transgender Rights under MGNREGA Act}

Majority (90.84 per cent) of the respondents in the scheme do not need this training on the rights of differently abled/pregnant ladies and transgender under MGNREGS Act. There was no differently abled/ transgender people associated with this scheme in the study area. Pregnant ladies are not allowed to be a part of this scheme in rural areas. So a meager 9.16 per cent has expressed training need on this Act.

\section{Training Preferences of MGNREGA Beneficiaries}

MGNREGA stakeholders has expressed their preferences on various training components, taking into account their family situation, resources at their disposal and time of farming activities. 
Table 2. Preferred Training area of MGNREGA Beneficiaries $(n=120)$

\begin{tabular}{lcc}
\hline Training preferences & Number & Per cent \\
\hline Type of Training & 96 & 80.00 \\
\hline Peripatetic training & 24 & 20.00 \\
\hline Institutional training & & \\
\hline Venue of Training & 108 & 90.00 \\
\hline Panchayat office & 12 & 10.00 \\
\hline Village School & & \\
\hline Duration & 108 & 90.00 \\
\hline One day & 12 & 10.00 \\
\hline Two days & & 70.00 \\
\hline Timing of Training & 84 & 30.00 \\
\hline Forenoon & 36 & \\
\hline Afternoon & & 23.33 \\
\hline Season of Training & 92 & \\
\hline Summer & 28 & \\
\hline Winter & & \\
\hline
\end{tabular}

From Table 2, the following inferences are drawn. Regarding the most needed training preference, as identified by the majority $(80.00$ per cent) of the respondents in this study was peripatetic training followed by 20 per cent preferring institutional training. Majority (90.00 per cent) of the respondents have preferred their own panchayat union office, followed by 10.00 per cent preferring their village school. Most of the respondents (90.00 per cent) preferred one day training programme and only 10.00 per cent needed training for two day period. Majority (70.00 per cent) of the respondents preferred forenoon training and remaining 30.00 per cent preferred afternoon trainings. More than three fourth (76.67 per cent) prefer summer season for training and the rest 23.33 per cent of the respondents preferred winter season.

\section{CONCLUSION}

It could be concluded from the above study that, majority to the MGNREGA respondents in this study identified the Checking multiple entries in job card, Active participation in Grama sabha meetings, Opening up of bank account/post office savings, Active participation in social audit, Work allocation procedure, Grievances Redressal mechanisms, Getting job card and Operation of accounts in bank/ post office as most needed training need areas. The majority of the respondents preferred to have peripatetic training in their own panchayat union office for a day during summer season on forenoon. Our policy planners, Administrators, Extension professionals need to make efforts to train MGNREGA beneficiaries on their felt needs to make it more effective and reach its intended objectives.

\section{REFERENCES}

Arti Pandit Dhawan and Ajay Kumar, 2017. Socioeconomic impact of Mahatma Gandhi National Rural Employment Guarantee Scheme (MGNREGS) in Himachal Pradesh, International Journal of Commerce and Management Research. Vol.3(11): 01-08.

Amarjeet Sinha, 2019. Making MGNREGS more useful, Times of India dated $22^{\text {nd }}$ November.

Ashokkumar, H. 2016. Performance of MGNREGA in Mysore District, Karnataka, International Journal of Research in Humanities and Social Studies, Vol.3: 1-7.

Badodiya, S.K., R.S. Kushwah, S.K. Garg and S.K. Shakya. 2011. Impact of Mahatma Gandhi National Rural Employment Guarantee Act (MGNREGA) on Poverty Alleviation, Rajasthan Journal of Extension Education, Vol.19: 206-209.

Benni, B.S. and J.Nagaraja. 2017. Women empowerment through Mahatma Gandhi National Rural Guarantee Act (MGNREGA) in Bellari District of Karnataka State, IOSR Journal of Humanities and Social Science, Vol.22: 26-30.

Gopinathan Rathika and Ramachandran Azhagaiah. 2017. Socio- Economic Determinants of Unskilled Workers of MGNREGA: A Study with Reference to Villianur Block of Puducherry Region, Pacific Business Review International, Vol.9: 100-111.

Gowhar Bashir Ahangar. 2014. Women Empowerment through MGNREGA: A Study of Shahabad District Blocks of Anantnag, Jammu and Kashmir, National Monthly Referred Journal of Research in Commerce and Management, Vol.3: 22-25.

Jean Dreze, 2020. The need for a million worksites now, The Hindu dated $25^{\text {th }}$ May.

Kunjithapatham, K.A. and D. Anand. 2015. Role of Mahatma Gandhi National Rural Employment Guarantee Scheme and its Impact on the Upliftment of Rural Population in Thiruvannamalai Distirct, Scholars Journal of Economics, Business and Management 2(12): 1172-1176.

Karma Loday Tamag, Bhuwan chhetri and Sandhya Devi Thapa.2016. Achievements and Constraints of MGNREGA in Sikkim, International Research Journal of Commerce Arts and Science, 7(9): 58-64.

Palanidurai, G. 2017. Unexpected consequences in Mahatma Gandhi National Rural Employment Guarantee Scheme, Janasakthi dated $16^{\text {th }}$ April.

Thirumal Kannan, V. 2019. SWOT Analysis on Mahatma Gandhi Rural Employment Guarantee Scheme (MGNREGS) in Dharmapuri District, Unpublished M.Sc (Ag.,) Thesis, Annamalai University, Annamalai Nagar -608 002. 